\title{
Thucydides and the Synchronous Pandemic
}

\author{
By Gregory T. Papanikos*
}

\begin{abstract}
Thucydides survived the pestilence and gave a vivid portrayal of the Athenian Epidemic at the onset of the Peloponnesian War. He belongs to the rare group of historians who wrote history about events which had a personal experience. He was involved with the war (as an Athenian strategos) and with the epidemic (had survived an infection). His History of the Peloponnesian War is a textbook approach of how historical events and facts should be researched and described. His historical methodology is based on an orthological analysis of human behaviour. Such an approach enables the researcher to interpret existing stylized facts and personal involvements with reason and objectivity. Within this framework, this paper examines Thucydides exposition of the epidemic of 430 BCE by means of four hypotheses which underline his historical analysis of the pestilence. Then, I proceed with the verification of these hypotheses using the data generation process of the synchronous pandemic of 2020. My main conclusion is that despite technological progress made by human beings with the graceful assistance of Prometheus, human nature did not change as much as Thucydides so eloquently emphasized, prognosed and hoped. Evidence on synchronous pandemic supports Thucydides diagnosis of the human nature but does not vindicate him on the hypothesis (or may be his wish) that his history would be used by future generations to avoid making the same mistakes over and over again. So far, the same or similar faults seem unavoidable. It appears that these faults are embedded in human nature and cannot be avoided.
\end{abstract}

\section{Prolegomena}

This paper aims to discuss the epidemic which ravaged Athens in the summer of 430 BCE; one year after the start of the Peloponnesian War which lasted 27 years (431-404). Thucydides immortalized the epidemic. He mentioned that the contagious disease was fearsome; many died but an exact number was not given. Littman (2009) stated that $25 \%$ of the Athenian population died (between 75 and 100 thousand people) but no source is cited ${ }^{1}$. Thucydides did make a reference to numbers when he described an unsuccessful military expedition of 4,000 Athenian soldiers to Potidaea. According to this (2.58), 1,500 or $37.5 \%$ of the soldiers died because of the disease. Earlier (1.23.3), he

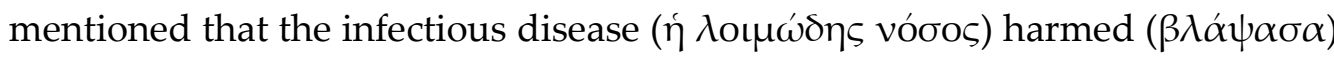
the population but no numbers were given either. In his book of Pericles (Parallel Bios ${ }^{2}$ ), Plutarch said that at the beginning of the outbreak, Pericles led a military expedition to the Peloponnese. Many of his soldiers died from the

"President, Athens Institute for Education and Research (ATINER), Greece.

1. J. F. D. Shrewsbury "The Plague of Athens," in Bulletin of the History of Medicine, 24, no. 1(1950): 1-25, used the same number and cited an earlier source of Hutton Webster, $A$ History of the Ancient World (London: George G. Harrap \& Company, 1915). Webster (1915, 235-236) stated that "The pestilence spread like fire and slew at least one fourth of the inhabitants of Athens". No source is cited here either.

2. Plutarch (46 AD-119 AD) wrote comparative biographies of selected Greek and Roman. In the case of Pericles, his life is compared to that of Fabius Maximus. 
disease but no statistics were given either. Thus, no one can quantify, with a certain degree of accuracy, the impact of the epidemic in terms of human losses. Later on (3.87), Thucydides himself made the same note, usually ignored by those who report numbers. Thucydides was very careful not to express qualitative assessments of historical facts as well, including social and political effects.

The epidemic lasted four years but its lethal effects occurred in two waves. The first in 430-429 BCE and the second in 427 BCE. According to Thucydides (3.87.1), however, the disease never disappeared ( $\dot{\varepsilon} \kappa \lambda \iota \pi 0 \tilde{v} \sigma \alpha \mu \dot{\varepsilon} v$

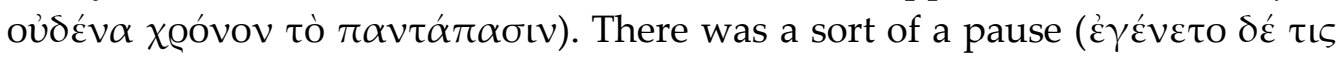

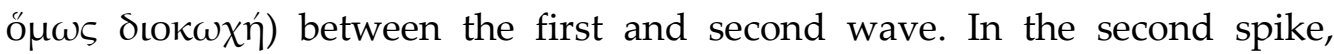
Thucydides (3.87.3) made a reference to numbers. He stated that the second

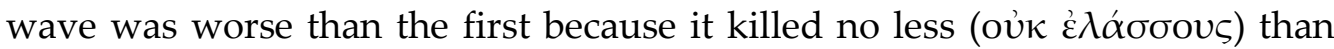
4,400 from the hoplites and 300 from the calvary ( $\tau \varepsilon \tau \varrho \alpha \kappa o \sigma i \omega \nu ~ \gamma \dot{\alpha} \varrho$ ó $\pi \lambda ı \tau \tilde{\omega} v$

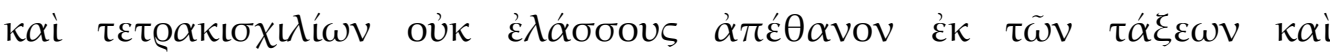
$\tau \varrho \iota \alpha \kappa o \sigma i ́ \omega \nu$ i $\pi \pi \varepsilon \dot{\varepsilon} \omega \nu)$. However, he was not able to provide a number for the

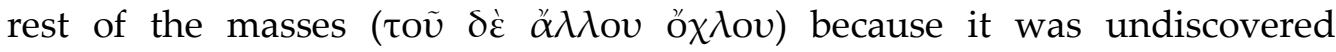

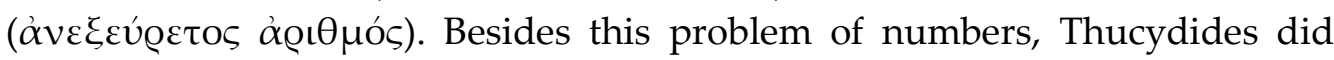
provide a detailed chronicle of the other aspects of the disease which are examined in this paper.

The emphasis here is on the social and political effects of the epidemic rather than on its microbial origins and its epidemiological severity. These etiologies of the ancient Athenian epidemic are not examined but some references are made as long as they relate to individual, social and political issues and reactions at the level of society and polity. These issues include housing, population density, water supply, transportation restrictions, food supply and the quality of health services.

As mentioned, Thucydides' History of the Peloponnesian War is the only contemporary source ${ }^{3}$. He used an analytical historical method -presented below- but many other methods of analyses of the ancient Athenian epidemic have also been used to discern the causes of the outbreak. Recently, archaeological evidence has been employed taking advantage of the more recent sophisticated

3. In his book Parallel Bios of Pericles, Plutarch made a number of references to the ancient Athenian epidemic. He cited other works which unfortunately have not survived, such as Theophrastus Ethics (HӨıкá). Nevertheless, even Plutarch himself based his Pericles Bios mainly on Thucydides. Most probably so also did others, since no one was a contemporary of Pericles. In these works, I do not include the work of various plays such as Aristophanes excellent trilogy on peace because they do not provide the information to evaluate the social and political aspects of the epidemic. For example, in the trilogy Aristophanes supports a peace agreement with Sparta but the majority of Athenians did not vote in favor in the Athenian Ecclesia of Demos. 
analyses of ancient DNA in preserved tissues ${ }^{4}$. Another source is the theatrical plays which described the plague and human reactions to it. These have been supplemented by philological criticisms ${ }^{5}$. There are many methodological problems with all these approaches, discussed in the relevant scientific literature ${ }^{6}$.

Apart from other problems, the historical analytical method suffers from “... translating any ancient foreign language are compounded by the fact that so many words in these languages have a variety of meanings. Additionally, due to the precision required in medical documentation, any word or phrase that is interpreted in a way other than that intended by the original author can skew a description toward or away from the actual diagnosis"7. In this paper, I use the original ancient text as the only source of information. The ancient relevant passages from Thucydides are cited but, in most cases, not literally (philologically) translated. Instead, the meaning or more accurately my own interpretation and understanding of it is outlined in the text.

4. See among many other studies Jennifer Manley, “Measles and Ancient Plagues: A Note on New Scientific Evidence," Classical World, 107, no. 2 (2013): 393-397; J. Longrigg, 'The Great Plague of Athens,' History of Science 18, no. 3 (1980): 209-25; Robert J. Littman, "The Plague of Athens: Epidemiology and Paleopathology," Mt Sinai journal of Medicine 76, no. 5 (2009): 456-67 B. Cunha, "The Cause of the Plague of Athens: Plague, Typhoid, Typhus, Small pox, or Measles?" Infectious Disease Clinics of North America, 18, no. 1 (2004): 29-43. Manolis J. Papagrigorakis et al., "DNA examination of ancient dental pulp incriminates typhoid fever as a probable cause of the Plague of Athens," International Journal of Infectious Diseases, 10 (2006): 206-214; Beth Shapiro \& Andrew Rambaut, "No proof that typhoid caused the Plague of Athens (a reply to Papagrigorakis et al.)," International Journal of Infectious Diseases 10 (2006): 334-340; J. C. F. Poole and J. Holladay, "Thucydides and the Plague of Athens," Classical Quarterly, 29 (1979): 282-300; Alexander D. Langmuir, et al., "The Thucydides Syndrome," New England Journal of Medicine, 313 (1985): 1027-30; Patrick Olson, "The Thucydides Syndrome: Ebola Déjà vu? (or Ebola Reemergent?)," Emerging Infectious Disease, 2 (Apr-Jun 1996) 1-23; Allison Brugg, "Ancient Ebola Virus?" Archaeology (Nov/Dec 1996): 28; Bernard Dixon, "Ebola in Greece?" British Medical Journal, 313 (17 Aug 1996): 430; Constance Holden, "Ebola: Ancient History of 'New' Disease?" Science, 272 (14 June 1996): 1591. Classicists along with medical scientists still debate today the exact cause of the plague. No consensus has been reached. Thucydides description of the disease which he contracted and survived himself is not sufficient to identify the medical cause and the nature of the infection. On the other hand, DNA tests have not helped either. The methodological problems are too severe to reach any definite conclusion.

5. See the discussion by Robin Mitchell-Boyask, "The art of medicine: Plague and theatre in ancient Athens," The Lancet, 373(2009): 374-375.

6. A concise summary of this literature is given by Cheston B. Cunha and Burke A. Cunha, "Great Plagues of the Past and Remaining Questions," in Paleomicrobiology: Past Human Infections, ed. D. Raoult and M. Drancourt (Berlin: Springer-Verlag Berlin Heidelberg, 2008): 1-20.

7. See Cunha and Cunha (2008, p. 4$)$ 
My reading of Thucydides suggests that he was more interested in the social and political consequences of the epidemic rather than making a diagnosis of its pathology (origin) and nature; and this shaped the reporting of his narrative. My received view of the entire history of Thucydides (including the passages on the epidemic) is consistent with his historical methodological analysis. This historical method is examined in the next section of the paper. Subsequently four hypotheses are presented; all of which relate to the social and political consequences of the disease. Each hypothesis is, then, examined in a separate section. For each hypothesis, I dare to compare and verify it for its diachronical validity against the background of the synchronous pandemic. The last section of this paper concludes.

\section{Thucydides' Historical Method and the Athenian Epidemic}

Thucydides wanted to be useful, not congenial. He wanted to teach, not to please. His scope was to benefit not only his own generation but all future generations. He thought that it is in the nature of people to make the same mistakes over and over again. He also wanted to teach the eternal human race how to avoid repeating the same or similar mistakes ${ }^{8}$. This objective applied to his description of the epidemic of 430 BCE. He used this event to generalize in an inductive way about all future epidemics. Thus, those who would want to learn what really happened could benefit from reading his history: to learn not for the sake of learning but to be prepared for the future if the same situation arises. This is the crux of Thucydides historical analysis. He wrote a useful

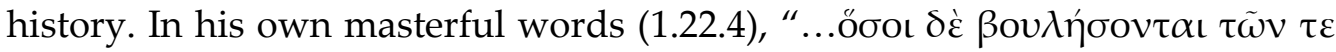

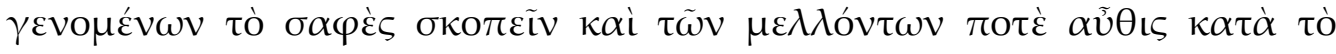

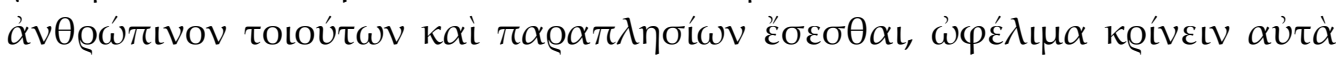

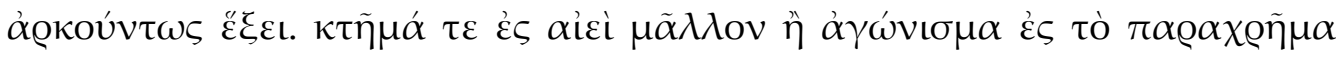

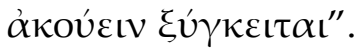

I like the word " $\alpha \gamma \omega \dot{v} \nu \sigma \mu \alpha$ ". My interpretation is that Thucydides is ironic here because some of his colleagues wrote history to please an audience. He most probably meant Herodotus. As always then and now, the masses

8. The apparent contradiction between human nature and human learning on how to avoid mistakes was not mentioned by Thucydides. If mistakes were the result of ignorance, then learning is useful. However, if they are the result of "human nature", they cannot be avoided because as Thucydides himself claimed people do not differ much. This is true across all generations; current and future. It seems to me that Thucydides was not vindicated on this issue as I will demonstrate with the metaphysical (superstitional), social and political effects of the synchronous pandemic. The effects of the 2020 pandemic are

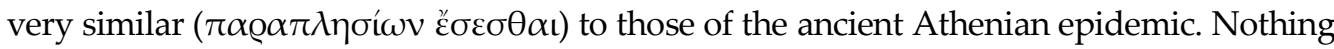
was learned, at least so far. After all, hope is what left in Pandora's Jar for the humanity to cherish. 
love to hear what they wanted to hear, e.g., they are the best and whatever they are doing is just and fair; the others (barbarians) are to be blamed.

He applied this approach in explaining the epidemic of 430 BCE. Thucydides, main description of the epidemic started right after Pericles' Funeral Oration, delivered to honor those who died during the first year of the Peloponnesian War. The relevant sections are from 2.47.1 to 2.65.13 of his book. However, as I have already stated, the epidemic was also mentioned in previous and later chapters. Reading these passages, I believe that Thucydides'

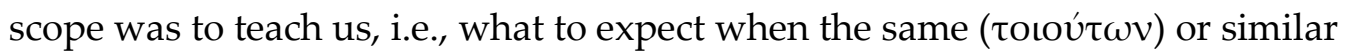
$(\pi \alpha \varrho \alpha \pi \lambda \eta \sigma i \omega v)$ things happen ( $\left.{ }^{\prime} \sigma \varepsilon \sigma \theta \alpha \mathrm{\iota}\right)$.

The synchronous pandemic of 2020 can be considered a similar one if not the same event at least in terms of its individual, social and political effects all of which are examined in this paper. What can we then learn from Thucydides' historical analytical account of the ancient Athenian epidemic and how does this compare with the synchronous pandemic? How did ancient Athenians react to the spread of the disease? These questions were not only sophisticatedly addressed by Thucydides but became, as he wished, a possession $(\kappa \tau \tilde{\eta} \mu \alpha)$ for all future generations to take advantage of it.

My approach (or better my own tactical method) of reading Thucydides is as follows. I view Thucydides' historical account as a series of testable hypotheses which can be verified (supported or rejected) against the background of similar events (facts) destined to ensue again. I apply this approach to the synchronous pandemic by developing four testable hypotheses. Thucydides thought they

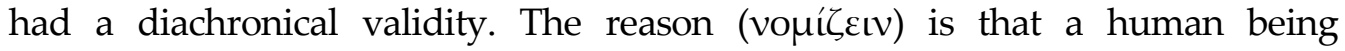

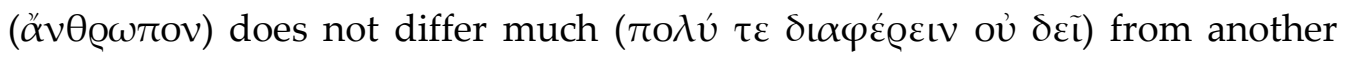
human being ( $\dot{\alpha} v \theta \varrho \omega ́ \pi \mathrm{rov})$ (1.84.4).

Thus, we may conclude that people will react the same way in the synchronous pandemic as did Athenians in 430 BCE. Is this the case? This paper aims to answer this question using the aforementioned hypotheses. These hypotheses are analyzed in the following sections of this paper. In the next section, though, I give a brief chronology of the epidemic based on Thucydides' "journalistic" account of it.

\section{The Chronicle of the Epidemic of 430 BCE}

After the victorious Persian Wars, in the first two decades of the $5^{\text {th }}$ Century BCE, Athens and Sparta were locked into what Graham Allison termed the

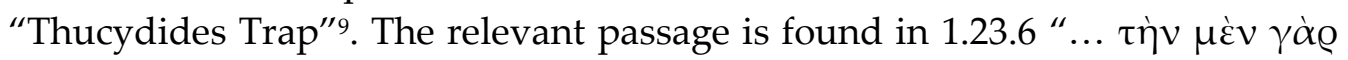

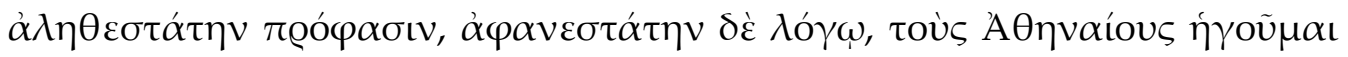

9. See Graham Allison, "The Thucydides Trap: Are the U.S. and China Headed for War?" The Atlantic, 24 September 2015, https://bit.ly/2yIU5KW. 


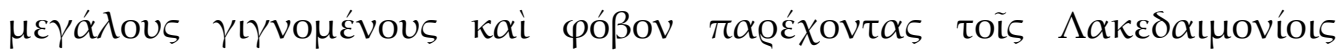

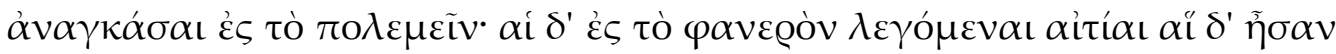

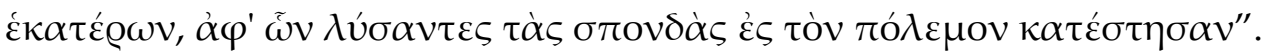

However, what Thucydides termed openly alleged causes (" $\varphi \alpha v \varepsilon \rho o ̀ v$

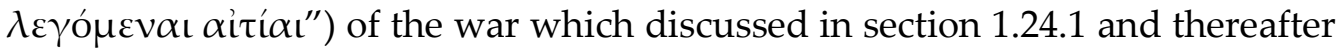
are very pragmatic reasons to enter into a war. So, what Thucydides stated that was the "Thucydidian Trap" was not what Allison claimed to be. Thucydides said that the war started because of the fear of Sparta that Athens would become great and overpower them. Spartans, therefore, had no other choice but to enter into war. However, a careful reading of Thucydides history would reveal that it was not the fear per se but a very solid and real economic reasoning of antithetical (economic) interests which brought the two cities and their allies into fierce antagonism and eventually into a war. As a matter of fact, after the Persian defeat, the entire $5^{\text {th }}$ Century BCE is characterized as a period of war between Athens and Sparta or their allies with short periods of truce. The idea that wars are always the result of economic conflicts was a common belief in the times Thucydides wrote his history. For example, in his

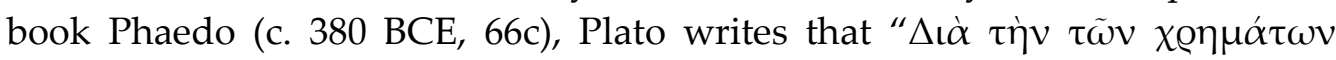

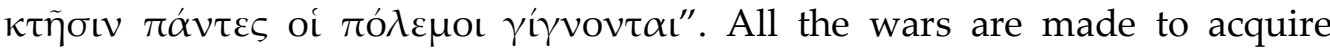
money.

The war then was inevitable. Despite a 30 years peace agreement, signed in $445 \mathrm{BCE}$, the famous war broke out in $431 \mathrm{BCE}$ and lasted, with some intermissions, 27 years. Athens was defeated but not because of the epidemic. Some claim that if the disease had not killed Pericles, he would have led them to a victorious result. If! However, as Pericles himself claimed -cited by Plutarch-, his military achievements were the result of good fortunate. If this were true (and I believe was true), then Pericles was not indispensable. After all Pericles could have been killed in one of the many battles he gave against the enemies of Athens. By 404, if not earlier, the epidemic had been long since forgotten.

As a matter of fact, when Nicias was addressing the Ecclesia of Demos in $415 \mathrm{BCE}$, arguing against the opportunistic and perilous expedition to Sicily, he reminded (6.12.1) the Athenians that they had just recovered from the great

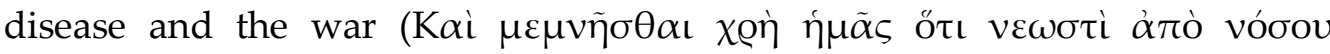

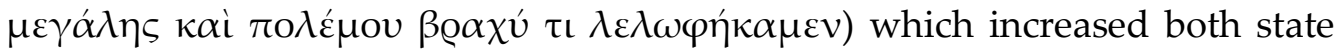

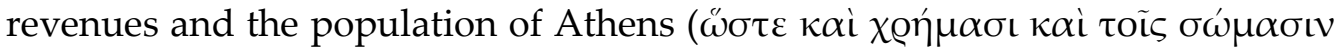
$\eta \dot{v} \xi \tilde{\eta} \sigma \theta \alpha \iota)$.

But Nicias could not persuade the Athenian Demos; they decided to send the army and navy to Cecily and actually under the military leadership of Nicias himself who was left alone after Alcibiades deserted to Sparta. Thucydides said (6.26.2) that Athenians were preparing their expedition because now they had accumulated public funds due to the truce and had soldiers at their disposal because many of the youth of Athens came of age to serve as soldiers 


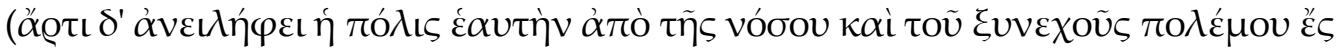

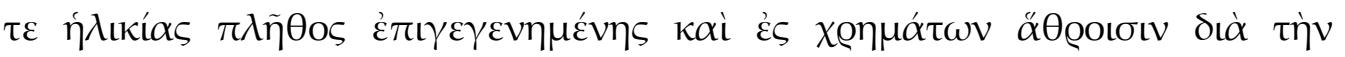

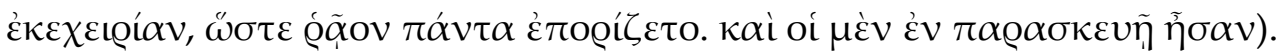

Thus, after 12 years Athenians had fully recovered and were able to undertake a dangerous military expedition that Pericles had so many times warned them against. Therefore, the loss of the war ten years later cannot be blamed on the epidemic. I am not sure if one could even blame it on the disastrous expedition to Sicily but the causes of the defeat are not my subject here.

One year after the war had started, in the beginning of the summer of 430 BCE, Sparta and their allies invaded again the land of Attica and camped outside its Long Walls. As in the previous year, they started their catastrophic praxes on the rural arable land of the surrounding areas of Athens known as Attika. After not many days, the disease (Vóøos) was born ( $\gamma \varepsilon v \varepsilon \dot{\sigma} \sigma \alpha \mathrm{l})$ among

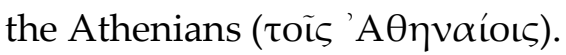

At this point, Thucydides gave some information. My reading has been as

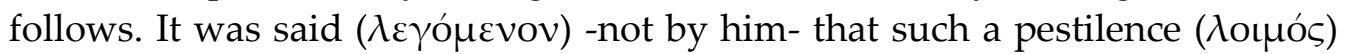

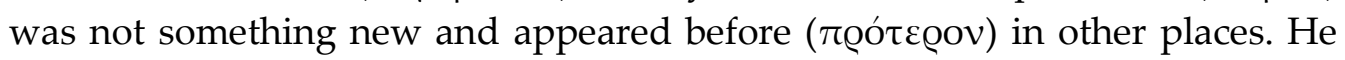
mentioned explicitly the island of Lemnos. But now there was a difference. All those who remembered or knew about previous outbreaks said that this was by far the most contagious and lethal epidemic. But this is a very common popular perception. What people encounter is always worse what they had experienced in the past.

On this issue, Thucydides was not helpful. He did not tell the future generations why Lemnos was explicitly mentioned. Perhaps here Thucydides acted as a "journalist" and reported what some Athenians said and discussed. Most probably some Athenians had a first-hand experience of a similar epidemic in Lemnos and this information was disseminated at the time.

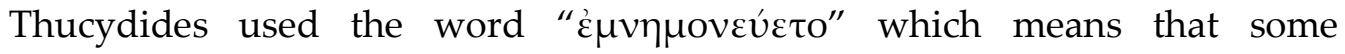
Athenians carried this information in their "memory". I interpret it that they had experienced the disease.

True or not, Thucydides did not take any stance on this issue. At this point, it is clear that he did not blame Lemnos or any other places. It seems that the plague of Athens was not related to the plague in those other places. The only conclusion that one draws from this is that some Athenians knew that such epidemics could occur because it happened in the past. So, they had learned their lesson and presumably they knew how infectious it could be and most importantly that it could be over in a few years.

Then, Thucydides continued with another "journalistic" report on what people thought of the origin of this epidemic. This is discussed in a following section of this paper. At the end of section 2.48, Thucydides stated that he was going to give an account of the symptoms of the plague so that if this happened again, the future generations will know. He based his description 
on his own experience with the disease because had not just suffered through a case of the illness, but had also been a part of the community of victims, family, urban neighborhood, that had survived and been marked by the

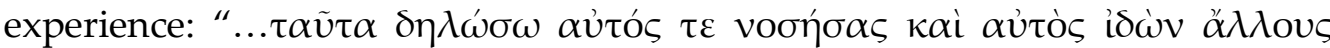
$\pi \alpha ́ \sigma \chi 0 \nu \tau \alpha \varsigma^{\prime \prime}$.

I am not going to state the symptoms described by Thucydides. I have already mentioned many works which presented and discussed these symptoms. No consensus has been reached. The nature and the medical cause of the disease are still debatable. There is only one-way to find out: if the same epidemic appears again, people will know. This is exactly what Thucydides told us. In

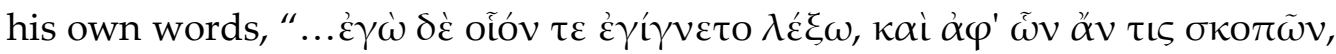

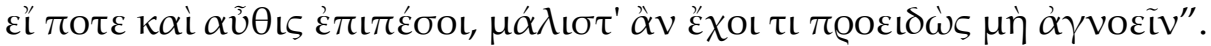

The meaning of this elegant excerpt is that Thucydides had only one

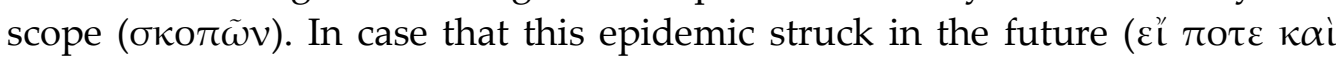
$\alpha \tilde{v} \theta ı \varsigma \dot{\varepsilon} \pi \iota \pi \dot{\varepsilon} \sigma o \iota)$, people will know and they will not ignore it ( $\mu \dot{\eta} \dot{\alpha} \gamma \nu 0 \varepsilon \tilde{\imath} v)$. This justification is consistent with the Thucydidian historical analytical method. But it may also be interpreted that, at least in the beginning, Athenians had underestimated the lethality of the disease. It seems that as a hypothesis is verified today by the initial reactions of some countries to the synchronous pandemic. As in ancient Athens, some countries today have ignored the synchronous pandemic despite Thucydides' warning of " $\mu$ ' $\dot{\alpha} \gamma$ voci $^{\prime \prime}{ }^{\prime 10}$. But many other testable hypotheses can be derived from Thucydides' historical interpretation of the ancient epidemic. These are discussed in the following sections.

\section{The Thucydidian Hypotheses about Pandemics}

My reading of the relevant passages on the ancient epidemic of 430 BCE is in the form of testable hypotheses using the historical analytical method. I assume that Thucydides developed a number of hypotheses; even though he did not mention them explicitly. I have categorized these hypotheses into four groups.

H1: Blame it on Foreigners and Enemies

H2: An Epidemic has Different Individual Effects

H3: An Epidemic Gives Rise to Metaphysical Explanations

H4: An Epidemic has Social and Political Consequences

10. A reader may point out that nobody reads Thucydides under the current calamity of the pandemic. On the contrary, there many articles in the international press which compare the ancient Athenian epidemic with the current pandemic. Thucydides would respond that it is in the human nature not to learn from past mistakes or experiences. 
In the following sections of this paper, I discuss separately each one of the above hypotheses.

\section{Blame it on Foreigners and Enemies}

I have already mentioned in the previous section that Thucydides said that Athenians knew that the same epidemic hit other areas as well, such as Lemnos, but no casual connection was made between these places and the epidemic that ravaged Athens in the summer of $430 \mathrm{BCE}$.

Instead, Thucydides cited two different sources from which Athenians thought the epidemic may came from. The first were the barbarophone as Homer would call them. According to the Thucydidian narration, as it was said ( $\omega \varsigma \lambda \dot{\varepsilon} \gamma \varepsilon \tau \alpha \mathrm{l}$ ), the epidemic first started in Ethiopia in the upper Egypt (most probably in modern Sudan); it went down to Egypt and Libya and then it outspreaded in the entire Kingdom. And suddenly ( $\dot{\varepsilon} \xi \alpha \pi \iota v \alpha i ́ \omega \varsigma)$ struck ( $\dot{\varepsilon} \sigma \varepsilon \dot{\varepsilon} \tau \sigma \varepsilon)$ Athens but not all at once. It first started in Piraeus and then came

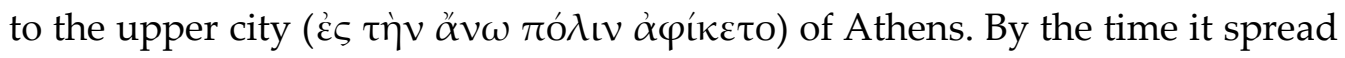
throughout the city, too many had already died ( $\varepsilon \theta v \eta \sigma \kappa o v ~ \pi о \lambda \lambda \tilde{\omega} \mu \tilde{\alpha} \lambda \lambda$ ov $\eta \delta \eta)$. Unfortunately, as previously mentioned, Thucydides did not give a number because it was unknown.

But there was a second theory which was said ( $\dot{\varepsilon} \lambda \dot{\varepsilon} \chi \theta \eta)$ during that time. Athenians blamed it on the Peloponnesians who threw ( $\dot{\varepsilon} \sigma \beta \varepsilon \beta \lambda \eta \dot{\eta} \kappa o เ \varepsilon v)$ the virus $(\varphi \alpha \dot{Q} \mu \alpha \kappa \alpha)$ into the wells ( $\dot{\varepsilon} \varsigma \tau \dot{\alpha} \varphi \varrho \varepsilon ́ \alpha \tau \alpha)$ of Piraeus which were used as drinking water because the area did not have fountains. And this relates to the fact that the epidemic started in Piraeus; then it spread throughout the city.

It seems to me that Thucydides did not accept any of these two allegations.

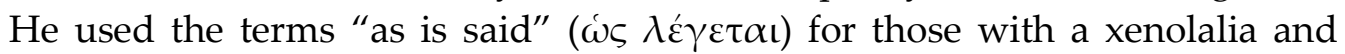
"was said" ( $\dot{\lambda} \dot{\varepsilon} \chi \emptyset \eta)$ for the Peloponnesians ${ }^{11}$. Thucydides was a rational thinker and would never accept such explanations as the real causes of a natural phenomenon like an epidemic. I think the dominant explanation was the first one because it persisted as an explanation and was still used at the time when Thucydides was writing on the Peloponnesian War. On the other hand, the other explanation most probably did not stand the test of time. Does this mean

11. On the use of the word $\lambda \dot{\varepsilon} \gamma \varepsilon \tau \alpha \iota$ and the different varieties by Thucydides see $\mathrm{H}$. D. Westlake, " $\Lambda$ EГETAI in Thucydides," Mnemosyne, Fourth Series, 30, Fasc. 4 (1977): 345362. On page 347 he explains the use of the word as follows "Few difficulties are presented by passages in which Thucydides uses a legetai phrase in a past tense, such as $\dot{\varepsilon} \lambda \dot{\varepsilon} \chi \theta \eta$ or $\omega \varsigma \dot{\varepsilon} \lambda \dot{\varepsilon} \gamma \varepsilon \tau$. In each passage he mentions a report or rumor current at the time which he cannot confirm or deny, though in most cases he is decidedly skeptical. He does not state the reason for his uncertainty, but it is more or less easily deducible from the context. His sources are undoubtedly oral". This is exactly my reading of the relevant passages. 
that Thucydides had adopted the former over the latter? Did he himself blame the barbarians over the fellow Peloponnesians? I do not think so at all. From an historical analytical point of view, the first hypothesis was difficult or impossible to verify. On the other hand, the second hypothesis was easily verifiable. Most probably there were many others drinking water from the wells of Piraeus and not infected. So, this hypothesis collapsed as a valid explanation ${ }^{12}$.

I do believe that Thucydides did not adopt either explanation. Just in the next sentence, after reporting the two explanations, he questions both rumors.

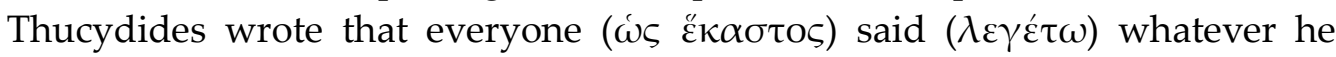

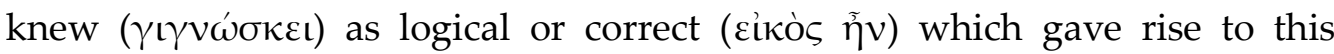

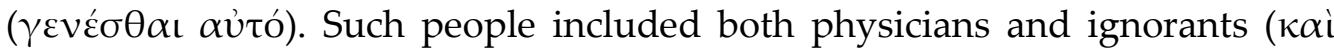
i $\alpha \tau$ ¡ò $\kappa \alpha i$ i $i \delta \omega \tau \eta \varsigma)$. He highlighted the ignorance of these epidemics, i.e., the speculation on the real causes of such diseases which in essence change the

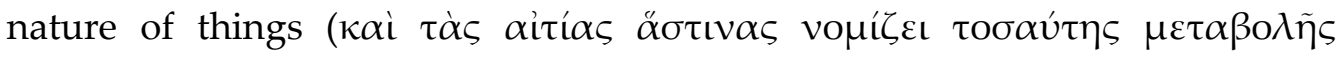

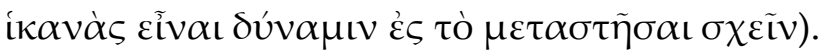

Thucydides said in this sentence that he could not explain the nature of the disease. Instead, what he could offer to the humanity was his own account of the plight because he was infected (and survived) and he had seen many others who were infected. He provided an excellent description of the symptoms but it seems that they are not sufficient for the modern virologists or epidemiologists to elucidate what was this epidemic all about. The issue is still debated. Thucydides' indirect admission that he could not tell anything about its causes ( $\tau \dot{\alpha} \varsigma \alpha \hat{i} \tau i ́ \alpha \varsigma$ ) shows that his history writing is based on logic and reason and not on what was said by ignorant people. If I may speculate about the nature of the epidemic, I would tend to agree with those who state that was something new which has not appeared yet again. If it reappears again, we would know it from Thucydides' excellent description of its symptoms.

Let me summarize this hypothesis. If an epidemic struck at a country, some people would blame it on foreigners. Is this hypothesis rejected by the synchronous pandemic ${ }^{13}$ No, it is not. The richest nation on earth, the one which produces an immense amount of new knowledge by using scientific methods and reason, has a President who blamed the pandemic on China. The President of the USA did not call it a coronavirus but a Wuhan virus, from the

12. The "blamed it on Spartans" did not live long. This is also supported by A. W. Gomme, A Historical Commentary on Thucydides, vol. 2 (Oxford: Clarendon Press, 1956).

13. I am not going to give any references to these sources. In many cases, these opinions have been covered up by "serious" think tanks. And the reason is not what they say but how they substantiate their argument. If someone says that the $\mathrm{X}$ country or the $\mathrm{Y}$ group of individuals spread the virus, they must have the evidence to support it. They do not. According to Thucydides they are the "idiots" in the English meaning of the word, which did not have the same meaning in Thucydides' time when it simply meant private individuals. 
area of China where the first symptoms appeared. Of course, China retaliated by stating that USA started it. The definition of barbarians is subjective. If you are Chinese, then the USA is barbarian. But if you are a US citizen, then it is the Chinese who are barbarians. So, blaming it on barbarians has stood the test of time as a hypothesis. It did not fade away.

Some take this hypothesis even further. They claim that this is part of a biological war. The soft version of this explanation alleges that this virus was born in the Chinese labs and it spread all over the world by a mistake. I heard the same thing about the HIV virus that was born in California Labs. Some even used this as an excuse to attack globalization. The strong version of this explanation is that this was not an accident. But there is a war of spies coming from all the big international political actors such as the USA, China, Russia etc. Even though I have read many journalistic reports about the role of spies in warning that a virus might generate a pandemic and/or the pandemic is instrumentalized by some countries in support of their international aspirations, I have seen the strong version of the explanation. As in Thucydides, I was only a bystander of discussions in downtown Athens (close to where Thucydides used to be present) who seemed to me they were adopting the argument of a biological war. When I pointed out that this was said in 430 $\mathrm{BCE}$ as an explanation of the ancient Athenian epidemic, nobody believed me.

As far as the first hypothesis is concerned, the current generation has not learned much from Thucydides warnings. One explanation might be that given by Thucydides himself: human nature does not change and people are similar if not identical across space and time.

\section{An Epidemic has Different Individual Effects}

Epidemics and pandemics show that men and women are not the same. Both the symptoms of the disease differ as a well as their attitudes towards it. Some are heroic and some run-away. Some are infected and they have an easy way out; others suffer and even worst die from it. In the beginning, Thucydides described the common characteristics as symptoms of the epidemic (Tò $\mu \dot{\varepsilon} v$

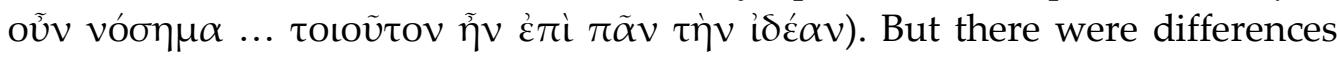
among those infected. These variations, however, are not mentioned. My explanation is that Thucydides' purpose was not to explain the disease itself for two reasons. Firstly, he was not writing about the disease but about the history of the war. Also, if he had not been infected himself, I do not think he would have ever dedicated so many lines to write about it. Secondly, he did not know anything about its causes and pathology. Thucydides decided to skip $(\pi \alpha \varrho \alpha \lambda \iota \pi o ́ v \tau \iota)$ the description of these additional symptoms which varied between individuals. 
As mentioned, some people were able to survive while others did not. This could not be explained either. Pericles, his sister and his two sons did not make it. But Thucydides survived. There was no medicine ( $(2 \alpha \mu \alpha)$ that could cure the disease. Prometheus did not bring any vaccines. He had other priorities. He brought them later. Thucydides mentioned that medicines which cured made others worse. Even the quality of health care did not help either. Those who had good health care $(\theta \varepsilon \varrho \alpha \pi \varepsilon v o ́ \mu \varepsilon v o \iota)$ were dying along with those who had no care at all $\left(\dot{\alpha} \mu \varepsilon \lambda \varepsilon i \alpha_{1}\right)$. All died irrespectively of the

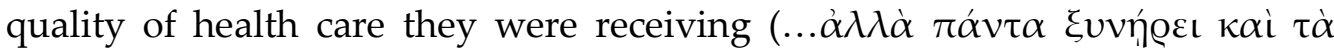

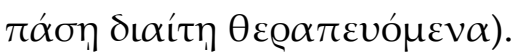

Thucydides observed that in the year of the epidemic (430 BCE), Athenians did not suffer from normal diseases; no other serious disease occurred apart from

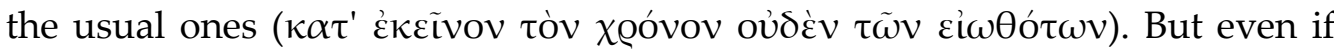
they appeared, all resulted in the same thing: people were eventually dying from the epidemic. Presumably those who had underlying (chronic) diseases were more vulnerable to the epidemic. Apart from this group of people at risk, Thucydides mentioned the medical staff as being vulnerable because they

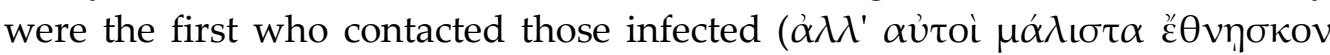
ö $\sigma \omega \kappa \alpha \grave{\iota} \mu \alpha \dot{\lambda} \iota \sigma \tau \alpha \pi \varrho 0 \sigma \tilde{\eta} \sigma \alpha v)$.

However, the difference was not restricted only to symptoms and the epidemiology. Most importantly it affected individual behaviour. I have already mentioned Pericles' change of behaviour and beliefs as cited by Plutarch. Some people were scared. They did not go near an infected person ( $\varepsilon$ lı $\tau \varepsilon \gamma \dot{\alpha} \varrho$

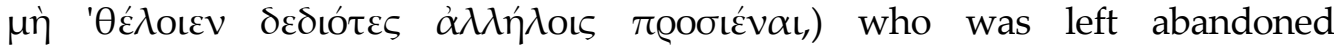

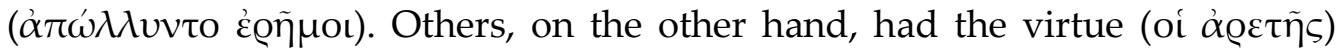
and felt ashamed ( $\alpha i \sigma \chi u ́ v \eta)$ to leave their friends to die alone. Worst of all

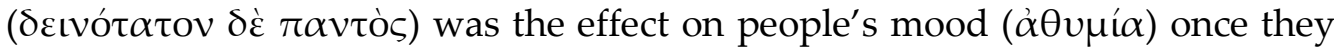
realized that they were infected. The result was hopelessness ( $\dot{\alpha} v \varepsilon \dot{\varepsilon} \lambda \tau \iota \sigma \tau o v)$

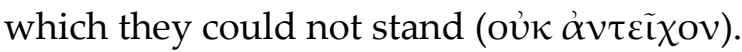

Thucydides also made an important observation that those who survived, like himself, were not infected a second time and even if they were infected,

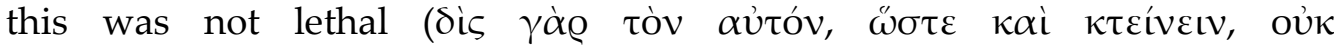
$\varepsilon \pi \varepsilon \lambda \alpha \dot{\alpha} \mu(\alpha v \varepsilon v)$. And these people were so happy that they thought for the time being that they would not die from any other disease. They were immune not to the disease which caused the specific epidemic but to all types of diseases. According to Thucydides, this was an "empty hope" (кoú $\varphi \eta \varsigma$ $\varepsilon \lambda \pi(\delta \circ)$ ); an expression that even today is used in Greece to describe vain hopes, which, nevertheless, make someone temporarily happy ( $\pi \alpha \varrho \alpha \chi \varrho \tilde{\eta} \mu \alpha$ $\pi \varepsilon \varrho \chi \chi \alpha \varrho \varepsilon \tilde{\imath})$. Thucydides mentioned that these people were very compassionate to those who were infected because they knew what they had to go through.

The synchronous pandemic does not reject any of the above observations. Firstly, there is a general idea of the symptoms of Covid-19, as in $430 \mathrm{BCE}$, but there are also many variations. Some even show no symptoms at all which 
might have been the case in ancient times. Secondly, as in 430 BCE Athens, in today's world of 2020, people are dying alone either in hospitals (nursing homes) or in their own houses without any help. Thirdly, even those who have the best of health care system (countries and individuals) cannot avoid death. It hits both the rich and the poor; the known and unknown persons. As in ancient Athens, the medical and nursing staff is the most vulnerable socialprofessional group. The current evidence does not reject this hypothesis even though today the available Personal Protective Equipment (PPE) have been well developed. In antiquity these were non-existent. Fourthly, similarly to ancient Athens no medicine can absolutely cure Covid-19. Today, as in ancient Athens, some medicine seems to work for some people, but it does not work for others. Despite all the progress in pharmaceuticals, epidemics and pandemics outsmart human ingenuity. Fifthly, people with underlying diseases (i.e., suffering from other diseases such as cardiovascular, kidney, diabetes, blood pressure etc.) are finally deceased from the Covid-19. This was the case in ancient Athens as well. Sixthly, one of the consequences of the disease for both those who were infected and those who were not is the feeling of isolation, desperation and depression. In ancient times, Thucydides told us that people were suffering from $\dot{\alpha} \theta v \mu i \alpha$ which can be translated as depression. Seventhly, today we do not really know whether people who are infected cannot be infected again and if they are infected whether they can die from it. Thucydides hands-on evidence did not reject the hypothesis of immunization, i.e. infected but survived people did not die if they happened to get infected a second time.

Finally, a note should made on the social or physical distancing. The war forced masses of people to move from the countryside behind the Long Walls of Athens where not only adequate houses were unavailable but people were forced to sleep in dirty and crowded huts. The connection of overcrowded places and the spread of the disease was clearly stated in Thucydides' discussion of the epidemic in two different parts. For the first time, Thucydides mentioned

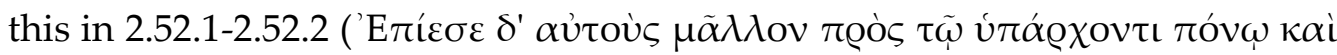

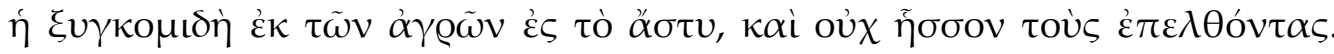

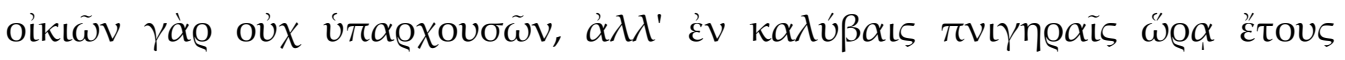

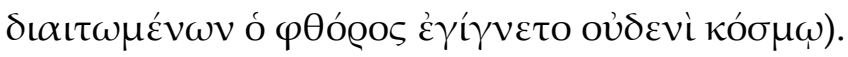

But this citation by itself does not show any link between the density of population and the spread of the disease because the emphasis is on the inconvenience of stay and the quality of housing. However, later on, in 2.54.5, Thucydides explicitly made the connection between the spread of the disease and the overcrowded Athens during this period. He wrote that in Athens and in other places with high population density ( $\tau \dot{\alpha} \pi \mathrm{o} \lambda v \alpha v \theta \varrho \omega \pi \hat{\tau} \tau \alpha \tau \alpha)$ the disease was more lethal.

Thucydides never suggested the idea of social or physical distance as a cure to the spread of the epidemic. Today humanity learned that distancing 
might be a good antidote to the spread and therefore the lethality of the disease. At last we found something that future generations learned from past mistakes.

\section{An Epidemic Gives Rise to Metaphysical Explanations}

The ancient epidemic could not be explained by scientific methods. The medical profession of the time could find neither the cause nor the cure ${ }^{14}$. Also, epidemiologists today and then could not find the source either. In such situations of ignorance, metaphysical explanations find fertile land to grow. Thucydides gave us two such explanations.

The first metaphysical explanation is based on an elegant story based on the spelling of two Greek words which phonetically sound the same: $\lambda \mu$ uo

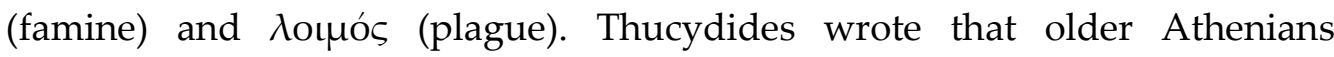
remembered an old saying which stated that "a Dorian war will come along

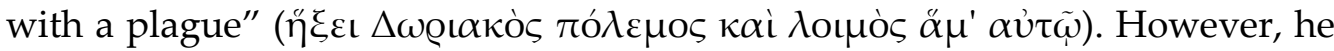
pointed out that the old saying was talking about $\lambda$ uós (famine) and not about $\lambda$ oupós (plague). Since this was a verse of a presumably larger piece of a poem, it went down from generations to genarations by the word of mouth (as all epic and didactic poetry or prose). Even though some disapproved of such an interpretation of the word -plague instead of the correct famine-, Thucydides

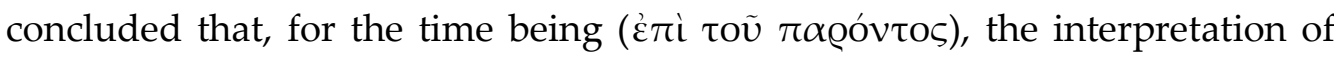

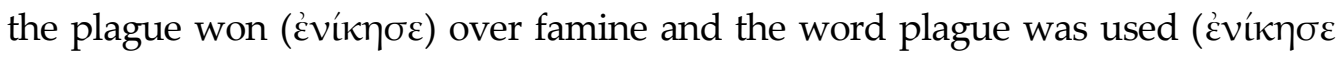

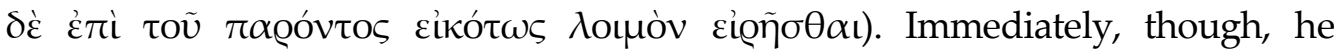
pointed out that if another Dorian War happened and was associated with a famine, then people will interpret the old saying differently. Why? Thucydides generalized his observation and said that it is in people's nature to adjust their

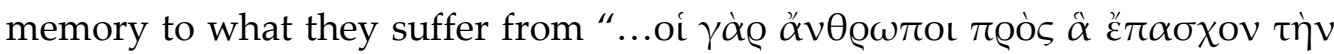

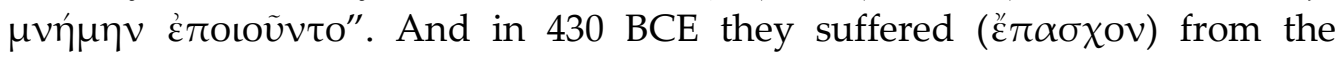
plague.

The second explanation had to do with the God Apollon. It is well known from Homer and in the Trojan War that Gods had taken sides with one or another army; with one or another protagonist (hero) of the war. Athenians remembered a prophesy given by the Oracle of Delphi which was a Temple of Apollon. Pythia told Lacedemonians that they would win the war if they

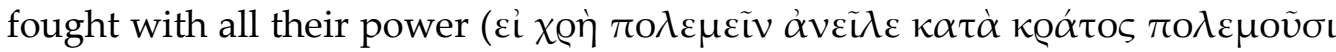

14. It is interesting to note that one of the participants in Plato's Symposium was

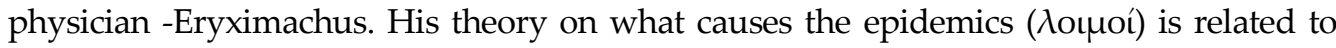
unjustified cosmic Eros (i.e., sexual encounters) and this is what brings the epidemics and

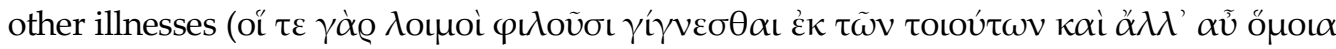

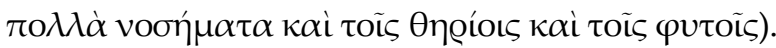




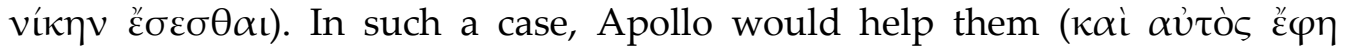
$\xi ט \lambda \lambda \eta \dot{\psi} \psi \varepsilon \sigma \theta \alpha \iota)$.

Thucydides wrote that Athenians believed that the epidemic was sent by Apollo to help the Lacedemonians because the pestilence started right after the Peloponessian War. Of course, if Athenians won the war, the Pythia could always argue that Lacedomonians did not fight with the required zeal ( $\kappa \alpha \tau \dot{\alpha}$

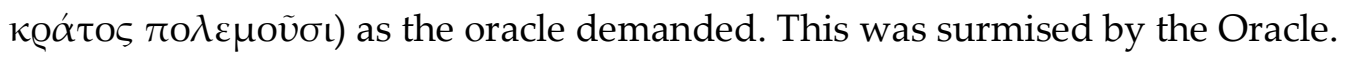
The Oracle (Gods) never makes mistaken prophesies. People interpret it the wrong way.

Related to this is a story told by Plutarch. In his work on Pericles, he wrote that Theophrastus used as an example (a case study) in his work on Ethics Pericles change of attitude when he was infected by the disease. Pericles, throughout his life and under the influence of his teacher Anaxagoras, had adopted an orthological approch in explaining natural phenomena. However, according to Plutarch, in his last years of life and under the influence of some women had an amulet in his neck to protect him from the disease. The way Plutarch mentioned that Pericles himself was showing this to his friends to demonstrate how personal sufferings can make someone believe in such a stupidity. This indicates to me that Pericles was not superstitious but was wearing the amulet to please his surroundings. I have seen this in modern Greece many times. People's logical reaction when asked about it, they say it does not hurt to wear it. Why does someone wear a decorated and colourful wrist watch and not a very simple one? I consider it a stoic approach to life.

I found another story reported by Dan (2008) ${ }^{15}$ citing L. Weber (1921) but the original source is Lucian of Samosata, the satirical author of the $2^{\text {nd }}$ century C.E. He records the following legend (vol. 2, p. 103) ${ }^{16}$ :

At the time of the great plague, the wife of Architeles the Areopagite had a vision: the Scythian Toxaris stood over her and commanded her to tell the Athenians that the plague would cease if they would sprinkle their back-streets with wine. The Athenians attended to his instructions, and after several sprinklings had been performed, the plague troubled them no more; whether it was that the perfume of the wine neutralized certain noxious vapours, or that the hero, being a medical hero, had some other motive for his advice. However that may be, he continues to this day to draw a fee for his professional services, in the shape of a white horse, which is sacrificed on his tomb. This tomb was pointed out by Dimaenete as the place from which he issued with his instructions about the wine;

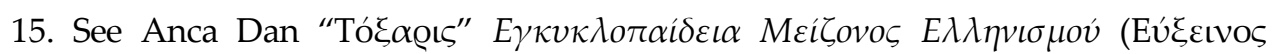
Пóvтos, 2008).

16. In The Works of Lucian of Samosata, tr. by H. W. Fowler and F. G. Fowler (Oxford: The Clarendon Press, 1923), vol. 2, pp. 102-109. 
and beneath it Toxaris was found buried, his identity being established not merely by the inscription, of which only a part remained legible, but also by the figure engraved on the monument, which was that of a Scythian, with a bow, ready strung, in his left hand, and in the right what appeared to be a book. You may still make out more than half the figure, with the bow and book complete: but the upper portion of the stone, including the face, has suffered from the ravages of time. It is situated not far from the Dipylus, on your left as you leave the Dipylus for the Academy. The mound is of no great size, and the pillar lies prostrate: yet it never lacks a garland, and there are statements to the effect that feverpatients have been known to be cured by the hero; which indeed is not surprising, considering that he once healed an entire city.

Apparently, Athenians practiced this -which most probaly worked as a kind of disinfection still used today, e.g., chlorine. Because of this apparent success Athenians treated him as the physisian-hero who saved many lives and every year they honored his memory.

In the sychronous pandemic of 2020, metaphysical explanations do not seem to be the norm. However, since the outset of Covid-19, Iran has sent the message that this disease was sent by God to punish the western civilization. But God punished Iranians as well. God did not exclude them from the pandemic. Apparently the sin and the infedility is independent of nationality and ethnicity.

In the USA metaphysical explanations thrive in all its religions. The argument of the nature of God -good or bad-, hasreappeared. From my reading of all the fiction and non-fiction literature of pandemics, I never encountered even one exemption to this rule. Diseases are sent by the mighty God. Any religion's God.

At least in ancient Greece there was a hope that a feud between Gods Appollo versus Athena and Poseidon- might save the non-mighty and mortal human beings. In the sychronous monotheist religions such a hope has vanished. It is not a progress but a regression. The Greek Orthodox Church partially allows for more than one God and of course its many Saints who can act independently. I have not seen any source which argues that the Gods or Saints of the Greek Orthodox Church had different opinions about the destiny of a specific human being. If you are protected even by one Saint of the Greek Orthodox Church then even God cannot intervene to change this good fortune. You see that in modern Greece. People who are saved from the Covid-19 say that God saved them or the Holy Mother saved them or a specific saint saved them. This plurality shows that Greeks never lost their memory ofthe Gods of Ancient Greece, with the sole exception I have already mentioned: nowdays Gods and saints do not fight between themselves, which 
I take as a regression. If one is protected by one, there is no right for others to intervene, and this includes the mighty God.

On the other hand, there is a number of writings that predicted an epidemic or pandemic but these were based on the statistical occurrence of such phenomena rather than considered God's Action. However, even in ancient times, Thucydides mentioned that these metaphysical explanations were abandoned at the end.

What priests and oracles had prophesized was entirely useless and in the end they distanced themselves because the disease has defeated them (ó $\sigma \alpha \tau \varepsilon$

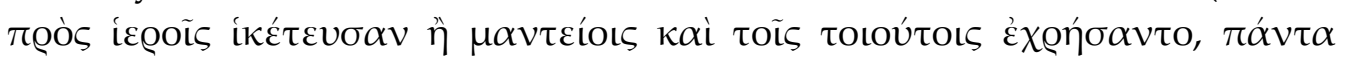

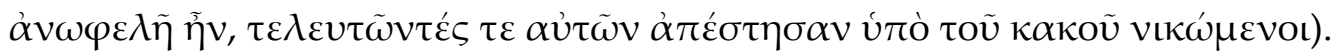

I am not sure that this claim by Thucydides had a universal application. I cannot conceptualize how someone may have lost his faith to God when he trusts that these diseases along with many other ordeals are sent by God to test people's confidence in him. This circular logic is at its best when is applied to people who believe in metaphysical explanations.

\section{An Epidemic has Social and Political Consequences}

Thucydides in 2.52-2.53 described Athenians' social reactions to the epidemic. I have already discussed individual reactions to the disease. Thucydides separated them from social impacts (including anthropological, economic, ethical and psychological) and political (including military) effects. Since then, humanity has learned that epidemics and wars change social and political attitudes. The ancient Athenian plague was not an exception. Epidemic and war co-existed.

One of the effects of the war, which I have already mentioned, was that Athenians were forced to move behind the Long Walls. This was a strategic military decision suggested by Pericles. From this political decision a number of social problems emerged. Overcrowded Athenians encountered difficulties in finding a place to stay. Space was extremely limited. They used even sacred monuments which was an early indication of violating social norms.

Once the epidemic struck, because of the seclusion of population in a small area, the infection spread immediately and people were dying like sheep. People were dying everywhere and without any help. One could see corpses everywhere. Thucydides observed that because of the high spread of the epidemic, people became indifferent to sacred places. Before no one was allowed to die inside a temple but now, because of the force of the epidemic, this custom was violated. However, even the social custom of burying changed dramatically without any respect for the way people were cremated and buried.

The social effect of the epidemic included the violation of law as well. Those who argued in favor of virtue (the good) had an increasing difficulty in 
persuading others as the epidemic persisted. They counter-argued that the disease did not discriminate between good (ethical, virtues) and bad (sinful, non-virtuous) people; between rich and poor; between loyal and non-loyal to the laws of the politeia. Thus, people lived for the moment and tried to enjoy their lives engaging in self-indulgences throughout whatever time they thought was left for them. When a rich person died, his property was stolen. Divine or man-made laws could not prevent such antisocial behaviour. Thucydides gave a logical justification or explanation (Eikò عĩv $\alpha \mathrm{l}$ ) of such behaviour arguing that people were not following the law because by the time they would have to face a court they might not be alive. What would be a greater punishment than the epidemic itself which was equivalent to a death penalty which, if inflicted could occur in less than ten days according to Thucydides' account. So, before the epidemic struck them ( $\pi \varrho i v \varepsilon \dot{\varepsilon} \mu \varepsilon \sigma \varepsilon i v)$, it

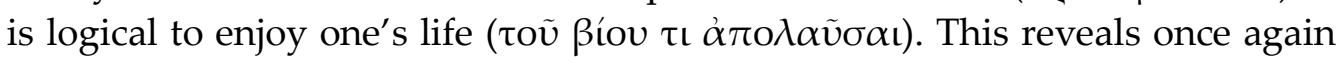
the orthological approach of Thucydides analysis of history.

The social upheaval created by the epidemic has a direct effect on the political process; especially when this co-exists with a war. Some Athenians blamed the whole situation on Pericles because he was the one who insisted going into war with Sparta. Thucydides links the two in 2.57. While the Peloponnesians were outside the Athenian Long Walls, the navy of Athens was active but the epidemic struck both the city of Athens and the army ( $\eta$

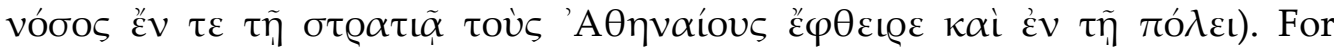
example, the expedition in Poteidia was not successful and the Athenian army of 4,000 soldiers lost 1,500 to the disease. At the same time, those douloi who escaped the city were informing the Peloponnesians what went on inside the city due to the epidemic; the latter information scared away the Peloponnesian who left Attica earlier than planned.

Thus, Athenians had to face the epidemic inside the city, the besieging Peloponnesians (destroying their fertile land and private houses) and the doulous who were escaping Athens. The political situation could not have been worse. The war started with the worse terms for Athenians. Some of them blamed all their misfortues to the war and the war on Pericles. Thus, they thought that it would have been a good idea if they could come to terms and sign a peace treaty with the Spartans ${ }^{17}$. Thucydides before citing Pericles'

17. Aristophanes' masterpiece -Acharnians performed in 425 BCE-, reflected this idea of a peace treaty with Sparta but the Athenian Demos was against it. This comedy was staged two years after the epidemic had disappeared and therefore could not play a role in changing the opinion of the majority of Athenians who wanted war. This is another indication that the war occurred not because of Pericles but because the majority of Athenians wanted it. The protagonist of the comedy, Dicaeopolis, owner of an agricultural property in the area of Acharnais is forced to stay behind the Long Walls leaving his land uncultivated. According to the play, he signed a private peace treaty with Sparta so that he could work on his land and enjoy all the fruits of peace. 
response to all these accusations made an excellent introduction-summary of the situation which existed in Athens just after the epidemic (2.59).

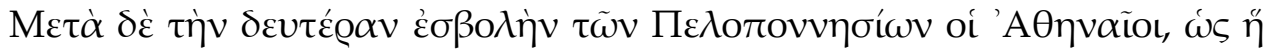

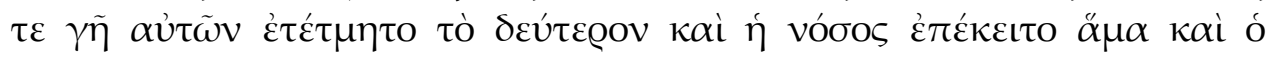

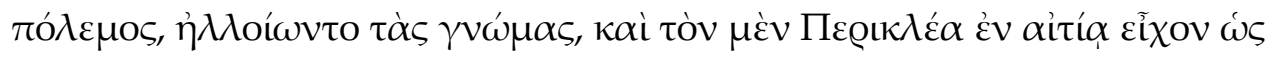

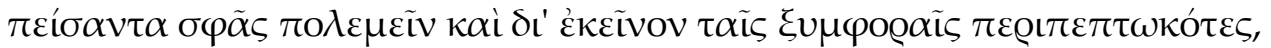

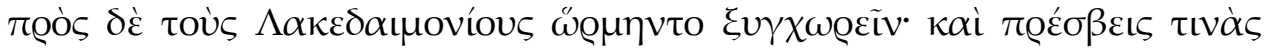

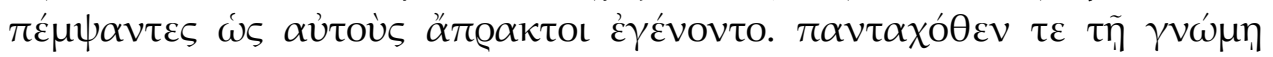

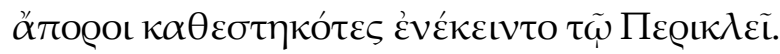

After the second invasion of the Peloponnesians in Athens, where they destroyed for the second time their land and the epidemic and the war were pressing, opinions about Pericles were changing and the reason was that he persuaded them to fight and because of him they were suffering and they were ready to compromise with the Lacedemonias. And they send respresentatives but nothing happened. In a such general deadlock they were against Pericles.

Pericles saw all these and with his usual determination and rhetorical skills gave Athenians courage and hope. Once again, Thucydides saved for the future generations another speech by Pericles in front of the Ecclesia of Demos. Pericles told the Athenian public that he was expecting such behaviour against him because he recognized that people were suffering from both the epidemic and the war. The purpose of his speech was to persuade Athenians that they did not treat him fairly. From what Thucydides has told us, Pericles was able to persuade Athenians to continue the war and he was able to be reelected as a leader. Unfortunately for him, his sister, his two boys and many of his friends and advisors could not survive the disease. The leaders who followed Pericles and led Athens did not meet the basic standards which their epoch and the situation of the war demanded. Nevertheless, Athens was able to counterbalance the Peloponnesian force and by 421 BCE they signed yet another peace agreement. Five years later the expedition to Sicily -contrary to Pericles's warnings in the beginning of the war-, brought Athens to its knees.

Pericles' speech was a long one and made many noticable observations which Thucydides presumably thought that future generations may benefit from. Pericles made clear from the beginning that a politeia can survive only if its citizens are united. This is not good only for the politeia but for each one individually. Secondly, the decision to go to war was a common decision and it is unfair now to blame it on Pericles alone. He built his argument saying that the reason Athenians changed their mind was the epidemic.

This points to the casual relations between the epidemic and the political and military developments. Pericles acknowledge Athenians were facing many 
problems such as the catastrophe of their property but most important one

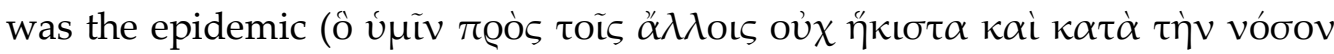
$\gamma \varepsilon \gamma \varepsilon \dot{v} \eta \tau \tau \alpha)$.

He recommended that Athenians set their personal grieving and sufferings aside and concentrate on the issue of common salvation $(\dot{\alpha} \pi \alpha \lambda \gamma \eta \dot{\eta} \sigma \alpha \nu \tau \alpha \varsigma \delta \dot{\varepsilon}$

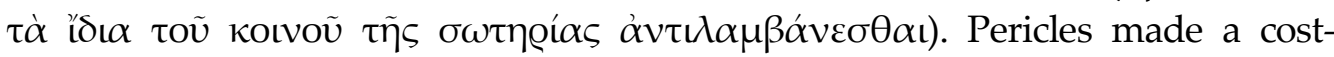
benefit analysis of what Athenians had lost so far (land and property) but keeping their greatest wealth intact, i.e., the navy power of Ancient Athens. Pericles concluded that if luck were to be distributed half and half between themselves and their enemies, then, in addition to hope, the boldness of Athenians would determine the outcome of the war.

Thus, Athenians should not have complained about the results of the war because these are things that one would expect from such a situation. But he did acknowledge that things were aggravated by the unexpected epidemic

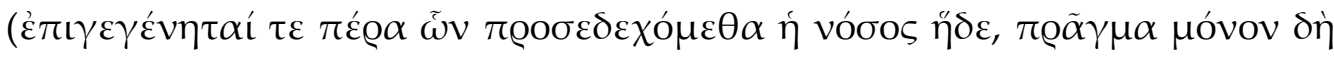

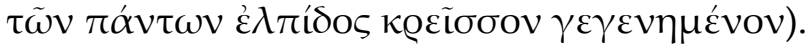

The decision by the Athenian Demos was not an easy one. Firstly, they decided to fine Pericles with an amount which is not mentioned by Thucydides. Secondly, they did not re-elect him as strategos. However, after one year, they elected him again as their leader because they admitted -as Thucydides mentioned- that he was the one who could lead them in such dificulty times.

Thucydides revealed that Pericles advised Athenians that they would win the war if they did not endeavour in new conquests (as they did years later in Sicily) and if they protected their city. According to Thucydides, Athenians did exactly the opposite. Based on these, Thucydides reached a conclusion which becomes a testable hypothesis: can democracy survive without good leaders? It seems to me that Thucydides' answer is no. This is how I interpret the section 2.65.10. Thucydides said that the political system of Athens was

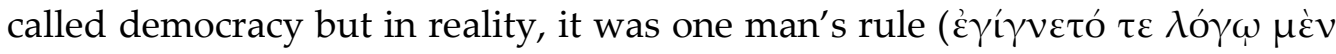

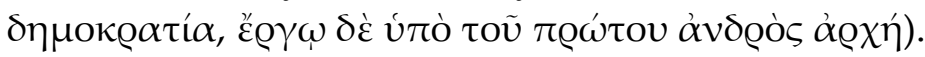

After two and a half years from the beginning of the war, Pericles died. Despite his early death, Athenians could easily have won the war if they had followed his advice. One may argue that if Pericles had survived the disease, Athenians would have emerged victorious. The epidemic had an impact on the outcome of the war because Athenians lost a great leader just in the beginning of this long Hellenic civil war. In $404 \mathrm{BCE}$ the end of the war found them defeated. It was the beginning of the end for the Athenian Classical 
(Golden) Age. And nobody can argue that the epidemic played any role ${ }^{18}$. By the end of the war, the epidemic had been forgotten. Thus, the political and social implications of epidemics and pandemics are destined to be short-run and they last as long as the disease itself last.

It is too early to draw any analogies with the current pandemic. Some early warning signals do support Thucydides hypotheses on social and political effects but only time will show. However, if the effects of the great epidemic of $430 \mathrm{BCE}$ are the rule, then the social and political reactions that we see today with the Covid-19 will be forgotten once the pandemic is over.

\section{Epilogue}

Thucydides was right, as human nature does not change. People do not differ not only across countries but across epochs as well. The only difference is in technology as so eloquently described by Hesiod in his Works and Days when making a reference to Prometheus.

Thucydides was wrong when he believed that writing his history would prevent future generations of the human race to avoid making the same mistakes again. The multitude of wars that followed the Peloponnesian War including the so many civil wars in Greece and elsewhere do not so far verify Thucydides' thesis. The mistake of a war, if it is a mistake, seems to be unavoidable.

On the other hand, the same applies to individual, social and political reactions to epidemics. Apart from some small differences, people and societies respond to epidemics and pandemics today in the same or in similar way as did the Ancient Athenians in 430 BCE. And while one might rightly think that a tremendous progress has been made in medical and pharmaceutical technology, the most fundamental problems remain the same when one compares the ancient Athenian epidemic with the current ecumenical pandemic. As in the ancient Athens, humanity today does not know the source, the microbial cause and the nature of the disease; it has not found a cure for the disease; the medical staff (doctors and nurses) were and still are today the most vulnerable groups of the society; and people who have underlying chronic history of illnesses have a higher probability of dying from it.

Social and political issues seem to be the same. As in the ancient epidemic so in the synchronous pandemic, some people, even head of states blame it on

18. Thus, I disagree with all those writers who claim that the epidemic had significant (long-run) military, political and social consequences. For an example of such a study see M.A. Soupios "Impact of the plague in Ancient Greece," Infectious Disease Clinics North America, 18 (2004): 45-51. The argument of Pericles lost in the epidemic cannot explain the defeat of $404 \mathrm{BCE}$ and the decline of Athens because Pericles would have died one day if nothing else from old age. In 404, if he lived, he would have been 90 years old. 
foreigners. Some go so far as to argue that it is part of a biological war; similarly, to what some Athenians thought about their epidemic. Comparable are the reactions to social norms. Today, as in ancient Athens, people are dying alone and are buried in mass graves. Some citizens blame it on their politicians. Even metaphysical explanations have not disappeared. In the synchronous pandemic, even the metaphysical explanations of God sending the disease to punish the sinful have been adopted by heads of states and religious leaders. It is interesting how similar does the world look today to the one of ancient Athens. The only difference is in technology.

After all these years, it seems only Prometheus has been working hard to change the material conditions. Unfortunately, philosophers and historians have not worked as hard to change people's non-orthological explanations of ecumenical phenomena.

\section{Acknowledgements}

The author would like to thank Nikos Nikoloudis, Nicholas Pappas, Yannis Stivachtis and David Wick for constructive comments. Remaining mistakes are author's intellectual property.

\section{Bibliography}

Allison, Graham. "The Thucydides Trap: Are the U.S. and China Headed for War?" The Atlantic, 24 September 2015. https://bit.ly/2yIU5KW.

Brugg, Allison. "Ancient Ebola Virus?" Archaeology (Nov/Dec 1996): 28.

Cunha, Cheston B. and Cunha, Burke A. "Great Plagues of the Past and Remaining Questions." In Paleomicrobiology: Past Human Infections, edited by D. Raoult and M. Drancourt. Berlin: Springer-Verlag Berlin Heidelberg, 2008.

Cunha, B. "The Cause of the Plague of Athens: Plague, Typhoid, Typhus, Small pox, or Measles?" Infectious Disease Clinics of North America, 18, no 1 (2004): 2943.

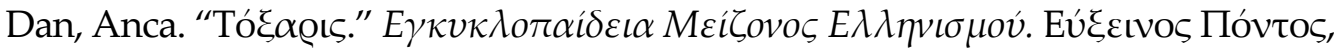
2008.

Dixon, Bernard. "Ebola in Greece?" British Medical Journal, 313 (17 Aug 1996): 430.

Gomme, A.W. A Historical Commentary on Thucydides, vol. 2. Oxford: Clarendon Press, 1956.

Holden, Constance . "Ebola: Ancient History of 'New' Disease?" Science 272 (14 June 1996): 1591.

Langmuir, Alexander D. et al. "The Thucydides Syndrome." New England Journal of Medicine, 313 (1985): 1027-30. 
Littman, Robert J. "The Plague of Athens: Epidemiology and Paleopathology." Mt Sinai journal of Medicine 76, no 5 (2009): 456-67.

Longrigg, J. 'The Great Plague of Athens.' History of Science, 18, no.3 (1980): 209-25.

Manley, Jennifer. "Measles and Ancient Plagues: A Note on New Scientific Evidence." Classical World, 107, no. 2 (2013): 393-397.

Mitchell-Boyask, Robin. "The art of medicine: Plague and theatre in ancient Athens." The Lancet, 373(2009): 374-375.

Olson, Patrick. "The Thucydides Syndrome: Ebola Déjà vu? (or Ebola Reemergent?)." Emerging Infectious Diseases, 2 (Apr-Jun 1996): 1-23.

Papagrigorakis Manolis J. et al. "DNA examination of ancient dental pulp incriminates typhoid fever as a probable cause of the Plague of Athens." International Journal of Infectious Diseases, 10 (2006): 206-214.

Poole, J.C.F. and J. Holladay. "Thucydides and the Plague of Athens." Classical Quarterly, 29 (1979): 282-300.

Shapiro, Beth and Andrew Rambaut . "No proof that typhoid caused the Plague of Athens (a reply to Papagrigorakis et al.)." International Journal of Infectious Diseases, 10 (2006): 334-340.

Shrewsbury J. F. D. “The Plague of Athens". Bulletin of the History of Medicine, 24, no. 1(1950): 1-25.

Soupios M.A. "Impact of the plague in Ancient Greece." Infectious Disease Clinics North America, 18(2004): 45-51.

Webster, Hutton. A History of the Ancient World.London: George G. Harrap \& Company, 1915.

Westlake, H. D. " $\Lambda$ EГETAI in Thucydides." Mnemosyne, Fourth Series, 30, no. 4 (1977): 345-362. 
